\title{
Symbolic Actions and Anti-royal Propaganda during a Political Crisis
}

\author{
D. Gh. Năstăsoiu
}

For citation: Năstăsoiu D. Gh. Symbolic Actions and Anti-royal Propaganda during a Political Crisis. Vestnik of Saint Petersburg University. History, 2021, vol. 66, issue 1, pp. 179-192.

https://doi.org/10.21638/11701/spbu02.2021.111

On Christmas Eve 1402, Hungarian noblemen gathered in the Cathedral of Nagyvárad, where St. Ladislas' tomb was located, and swore an oath on the holy king's relics. They proclaimed thus their allegiance to King Ladislas of Naples and conspired against the ruling King Sigis-

Dragoş Gh. Năstăsoiu - PhD, Research Fellow, National Research University Higher School of Economics, 20, Myasnitskaya ul., Moscow, 101000, Russian Federation; MECERN Researcher, Central European University, 9 Nádor, Budapest, H-1051 Hungary / 51 Quellenstraße, Vienna, A-1100, Austria; dragos_nastasoiu@yahoo.com, dragos.nastasoiu@hse.ru

Драгош Г.Настасою - PhD, науч. сотр., Национальный исследовательский университет «Высшая школа экономики», Российская Федерация, 101000, Москва, ул. Мясницкая, 20; исследовательский проект MECERN при Центрально-Европейском университете, Венгрия, Н-1051, Будапешт, ул. Надор, 9 / Австрия, А-1100, Вена, Квелленштрассе, 51; dragos_nastasoiu@yahoo.com, dragos.nastasoiu@hse.ru

The results of the project Symbolic Behavior in the Middle Ages and Early Modern Period carried out within the framework of the Basic Research Program at the National Research University Higher School of Economics (HSE) in 2018 are presented in this work. A version of this paper was read at the Fourth Medieval Workshop in Rijeka, Faculty of Humanities and Social Sciences of the University of Rijeka, 30-31 May 2019. I am grateful to the organizers, Dr. Kosana Jovanović and Dr. Suzana Miljan, for this opportunity. This initial paper focused on both the anti-royal propaganda during the 1401-1403 political crisis in the Kingdom of Hungary generally and on its reflection in the art commissioned by Hungarian noblemen around this complex period, in particular. For editorial reasons, I have divided this research into two distinct parts, the present one focusing on anti-royal propaganda, symbolic actions, and heraldic representation. The second part - dealing with the Hungarian noblemen's support of the cult of St. Ladislas, their pious and artistic patronage, and strategies of heraldic self-representation - will be published in one of the future issues of this journal. These two studies are, nonetheless, a unitary work.

В данной научной работе использованы результаты проекта «Символическое поведение в Средние века и раннее Новое время», выполненного в рамках Программы фундаментальных исследований НИУ ВШЭ в 2018 г. Версия этой статьи была прочитана на Четвертом семинаре средневековых исследований на факультете гуманитарных и социальных наук Университета Риеки, 3031 мая 2019 г. Благодарю организаторов - доктора Косану Йованович и доктора Сузану Милян - за эту возможность. Первоначально данная статья была посвящена пропаганде антикоролевских идей во время политического кризиса 1401-1403 гг. в Королевстве Венгрия, как в политической жизни в целом, так и ее отражению в памятниках искусства, созданных по заказу венгерских дворян. Из редакционных соображений представление результатов этого исследования разделено на две отдельные части: настоящая статья посвящена пропаганде антикоролевских идей, символическому поведению политических фигур и геральдическим изображениям. Вторая часть, посвященная поддержке венгерскими дворянами культа святого Ласло, формам религиозного благочестия и покровительства искусству, а также стратегиям геральдической саморепрезентации, будет опубликована в одном из следующих номеров журнала. Тем не менее эти два исследования представляют собой единое целое.

(C) St. Petersburg State University, 2021 
mund of Luxemburg. By swearing an oath on St. Ladislas' relics, the conspirators united their minds and forces around the ideal figure of the holy king and knight who became the symbol of a political cause and the embodiment of the kingdom which King Sigismund was no longer suited to represent. The symbolic gesture of oath-swearing on St. Ladislas' relics took place in the midst of a three-year political crisis (1401-1403) that seized the Kingdom of Hungary as a consequence of the barons' dissatisfaction with King Sigismund's measures, which jeopardized their wealth and political influence. By relying on both written accounts and visual sources, the present paper examines the utilizing by Hungarian noblemen during this political crisis of important political and spiritual symbols associated with the Kingdom of Hungary. These included: the cults, relics, and visual representations of St. Ladislas, the Hungarian Holy Crown, or the kingdom's heraldry. The propagandistic usage of these spiritual and political symbols was reinforced by their insertion into elaborated rituals and symbolic actions, such as coronations or oath-swearing on relics. By activating the link between secular and religious spheres through these rituals and symbolic actions, their performers hoped to attract the divine approval. By discussing such instances, the present paper seeks to illustrate how the ideal figure of St. Ladislas became the catalyzing force behind a political cause.

Keywords: St. Ladislas, King Ladislas of Naples, medieval Hungary, cult of saints, relics, symbolic actions, heraldry, anti-royal propaganda, Hungarian political crisis of 1401-1403.

\section{Символические действия и пропаганда в условиях венгерского политического кризиса}

\section{Д. Г. Настасою}

Для цитирования: Năstăsoiu D. Gh. Symbolic Actions and Anti-royal Propaganda during a Political Crisis // Вестник Санкт-Петербургского университета. История. 2021. Т. 66. Вып. 1. С. 179-192. https://doi.org/10.21638/11701/spbu02.2021.111

В канун Рождества 1402 г. венгерские вельможи собрались в соборе города Надьварад, где находилась гробница Св. Ласло, и принесли клятву на мощах святого короля. Таким образом, они объявили о своей верности королю Неаполя Владиславу и организовали заговор против правящего Сигизмунда Люксембурга. После присяги, принесенной на мощах Св. Ласло, заговорщиков объединила символическая фигура святого короля и рыцаря, ставшего эталонным воплощением политических идеалов и самого королевского титула, которому правящий Сигизмунд Люксембург больше не соответствовал. Символический жест принесения присяги на мощах св. Ласло был предпринят в разгар трехлетнего политического кризиса (1401-1403), охватившего Венгерское королевство вследствие недовольства баронов курсом короля Сигизмунда, ставившим под угрозу богатство и политическое влияние этих магнатов. Опираясь как на письменные, так и на художественно-изобразительные источники, настоящая статья исследует феномен использования дворянами важных политических и духовных символов, связанных с Королевством Венгрии, в ходе описанного политического кризиса. К таким символам относятся: культ, реликвии и изображения св. Ласло, венгерская Священная корона и государственная геральдика. Использование этих духовных и политических символов в качестве инструментов политической пропаганды сопровождалось и усиливалось их включением в тщательно продуманные социальные, публичные и политические ритуалы и символические действия, такие как коронация и принесение клятв. Таким образом, эти церемонии и символические акты были призваны установить связь между светской жизнью общества и сферой сакрального. Их участники видели в использовании священных предметов свидетельства участия бога в политических процессах королевства, а успешное проведение и завершение таких церемоний пони- 
малось как одобрение выбранного политического курса со стороны небесных сил. Рассматривая данные примеры, статья анализирует популяризацию св. Ласло в качестве образа идеального правителя и значение этих идей в политической практике.

Ключевые слова: святой Ласло (Владислав), король Владислав Неаполитанский, средневековая Венгрия, культ святых, реликвии, символические действия, геральдика, антикоролевская пропаганда, политический кризис 1401-1403 годов.

On Christmas Eve 1402, a number of Hungarian noblemen gathered in the Cathedral of Nagyvárad (Germ. Großwardein, Rom. Oradea Mare), where the tomb of St. Ladislas was located, and swore an oath on the relics of the holy king, who reigned between 1077 and 1095 and was canonized in 1192. Through their gesture and in opposition to the ruling king, Sigismund of Luxemburg (r. 1387-1437), these Hungarian noblemen proclaimed their allegiance to King Ladislas of Naples (r. 1386-1414), a claimant to the Hungarian throne on the basis of his Angevin lineage. By relying on both written accounts and visual sources, this essay examines the utilizing by the anti-Sigismund party of important symbols that were associated with the Kingdom of Hungary. Political and spiritual alike, these included: the cult and relics of St. Ladislas; the Hungarian Holy Crown; or the kingdom's heraldry. The Hungarian noblemen's appeal to the ideal figure of St. Ladislas made the holy king and knight become the catalyzing force behind a political cause and transformed him - yet again - into a powerful symbol of the country ${ }^{1}$. In addition to the utilization of the realm's political and spiritual symbols, the anti-Sigismund party performed various symbolic actions that were meant to prove the legitimacy of its cause. By describing the complex political events of the early- $15^{\text {th }}$ century and by emphasizing how the anti-Sigismund coalition made use on this occasion of St. Ladislas' relics, and how it actually performed a number of symbolic actions, this essay paves the way for another study, which will be published in the third issue of the same journal. The second essay will be dedicated to the artistic and pious patronage of those Hungarian noblemen that were directly involved in the early- $15^{\text {th }}$ century political crisis, highlighting how the cult and images of St. Ladislas and the other two Holy Kings of Hungary were utilized for expressing political and propagandistic messages, and how the realm's heraldry became a means of self-representation for these political actors.

Lasting from the spring of 1401 until the winter of 1403, this crisis was the last of a long period of political unrest following the death of King Louis I "the Great" (r. 13421382) and the extinction of the Hungarian Angevins' male line. This two-decade period was characterized by a constant challenging of royal authority ${ }^{2}$. Dissatisfied with King Sigismund's high dependence on his foreign counselors and fearing that their considerable wealth and political influence might come to an end, the country's barons impris-

${ }^{1}$ For a bibliographical overview up to 2007 of St. Ladislas' cult, see: Kerny T. Szent László tiszteletének kutatástörténete (1977-2007) // Arrabona. 2008. Vol.46, iss. 1. P. 15-35. After this date, see especially: Klaniczay G. A Szent László kultusz kialakulása // Nagyvárad és Bihar a korai középkorban. Tanulmányok Biharország történetéről. Nagyvárad, 2014. P.7-39; Solymosi L. Szent László király sírja, kultusza és szentté avatása // Szent király, lovágkirály. A Szent László-herma és koponyaereklye vizsgálatai. Győr, 2017. P. 16-39.

${ }^{2}$ For this period's history, see especially: Engel P. The Realm of St Stephen. A History of Medieval Hungary, 895-1526. London, 2001. P. 195-208; Hóman B. Gli Angioini di Napoli in Ungheria 1290-1403. Rome, 1938. P. 512-527; Burkhardt J. Ein Königreich im Wandel: Ungarn um 1400 // Biuletyn Polskiej Misji Historycznej. 2016. Issue 11. P. 407-437. Another work, Bard I. M. Aristocratic Revolts and the Late Medieval Hungarian State, A. D. 1382-1408. Washington, 1978, was not available to me. 


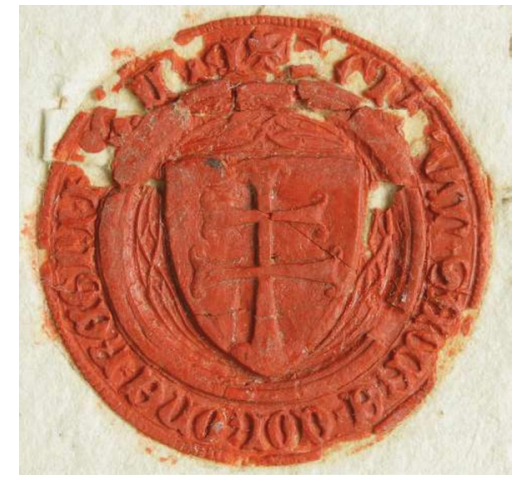

Fig. 1. Impression of the seal of the Council of the Holy Crown, 26 August 1401, red wax, diameter 3,4 cm (Magyar Nemzeti Levéltár, Budapest) oned the king in the Castle of Buda (28 April 1401). Led by Archbishop of Esztergom John Kanizsai (1387-1418) and by Palatine Detre (Detricus) Bebek (1397-1402), the Hungarian magnates formed a council composed of prelates and barons, which assumed the governing of the country and carried legal transactions under the authority of the Holy Crown regarded now as vacant ${ }^{3}$. Styling himself Chancellor of the Crown, John Kanizsai commissioned on that occasion a special seal, which had the inscription sigillvm sacre corone regni Hungarie and featured prominently a shield decorated with the Hungarian double cross $^{4}$ (Fig. 1). This heraldic symbol was first introduced by King Béla III (r. 1172-1196) as a symbol of royal majesty which - by the end of the $14^{\text {th }}$ century - came to symbolize the realm (regnum) as opposed to the changing person of the king (rex $)^{5}$. By calling it corona regni instead of the former corona regis, the community of the realm expressed in this way the noble commonwealth's claim to sovereignty. They established an authority whose representatives were the noblemen themselves and which was above the will of the king, loyalty being thus owed not to the monarch's concrete person, but to the abstract concept of the Holy Crown ${ }^{6}$. In fact, as it emerges from a document issued on 24 May 1403, the council's purpose was to bring together the Hungarian nobility and to create a sense of belonging to a community that directed its efforts to the general good of the realm. One of the means of achieving this public good was the election and coronation of a new king ${ }^{7}$.

Released after four months of captivity in the Castle of Visegrád (31 August 1401), King Sigismund was restored to his throne by the agreement of Pápa (29 October). His release was arranged by Sigismund's faithful supporter, Nicholas Garai, who handed over his own son and brother as hostages and who brought the king to his castle in Siklós ${ }^{8}$. The parties' temporary reconciliation was confirmed through a symbolic gesture performed by the contested king who took a solemn oath on the relic of the Life-giving Wood of the

3 Engel P. Realm of St Stephen. P. 206; Szentpétery I. Az országos tanács 1401-ben // Századok. 1904. Issue 38. P.759-767.

4 DL 87685, Magyar Nemzeti Levéltár, Budapest. Ibid., P. 766-767; Deér J. Die Heilige Krone Ungarns. Vienna, 1966. P. 187, Fig. 373; Marosi E. Magyarországi müvészet 1300-1470 körül. Budapest, 1987. Vol. 1. P. 99, 646.

${ }^{5}$ Kumorovitz B. L. A magyar címer kettőskeresztje // Turul. 1941. Vol. 55, iss. 3-4. P. 45-62; Bertényi I. Címerváltozatok a középkori Magyarországon // Levéltári közlemények. 1988. Vol.59, iss. 1. P.7-44.

${ }^{6}$ Bak J. M. Königtum und Stände in Ungarn im 14.-16. Jahrhundert. Wiesbaden, 1973. P. 33-35.

7 “...in hoc presenti negotio per nos deo propitio utique ad utilitatem et augmentum reipublice previe inchoato pre suis participibus reddidit se multipliciter commendabilem, utilem et agilem se ipsum et queque bona sua ad rotam fortune exponendo anhelatque in futurum totis viribus ad premissa prompto promptior inveniri, nos itaque reipublice utilitatem exinde resultare arbitrantes et ut ipse ceterique per eum exemplati ad prosecutionem publice et communis utilitatis eo reddantur ad promptiores et magis attenti $\langle\ldots\rangle$ a domino nostro futuro rege Hungarie, quem nos dei favente clementia super solium regni Hungarie in proximo in regem coronabimus..." (emphasis mine) - Šišić F. Nekoliko isprava iz početka XV st. // Starine. 1938. Issue 39. P. 203 (doc. no. 48).

${ }^{8}$ Engel P. Realm of St Stephen. P. 206-207. 
Holy Cross and committed to meet the demands of the council's members ${ }^{9}$. Soon after, however, King Sigismund acted as if his imprisonment had never occurred and began to reinforce his authority through a series of measures that provoked again the Hungarian magnates' discontent. Adding insult to injury, Sigismund refused to get rid of his foreign supporters and betrothed Barbara, the daughter of the Styrian Count Hermann II of Cel$\mathrm{je}^{10}$. After King Sigismund removed Detre Bebek from the office of palatine and replaced him with Nicholas Garai ${ }^{11}$, the anti-royal coalition swore allegiance to Ladislas of Naples who - as the only remaining male Angevin - had previously voiced his claims to the Hungarian throne and had already prepared an army waiting in Dalmatia ${ }^{12}$.

On Christmas Eve 1402, while King Sigismund was still in Bohemia helping his brother, King Wenceslas IV (r. 1378-1419), the Hungarian noblemen took a solemn oath of allegiance to Ladislas of Naples, swearing on the relics of St. Ladislas that were kept in the holy king's cult center, the Cathedral of Nagyvárad ${ }^{13}$. This episode is known from a royal charter issued five years later (1 August 1406) which rewarded the loyalty of Nicholas and John Garai with estates in Liptó County ${ }^{14}$. Several important details bearing a highly symbolical character show that the action was carefully planned. First, it was initiated and headed by the leader of the anti-Sigismund coalition (Archbishop of Esztergom John Kanizsai), who also held the country's highest ecclesiastical dignity for that matter. Second, the oath-swearing took place both during sacred time (on Christmas Eve) and in a sanctified place (at the cathedral's main altar). Third, the oath was performed on St. Ladislas' holy relics, thus meaningfully binding the oath-takers before both the Hun-

9 “... inuicem sincere reconciliati fuimus, omnem conceptum maleuolum rancoris et displicentiae de corde nostro prorsus abiiciendo; ideo ex certa nostra sciencia et libera voluntate et bona fide nostra, tacto viuificae crucis ligno, iure iurando promittimus et assumimus..." (emphasis mine) - Fejér G. Codex diplomaticvs Hvngariae ecclesiasticvs ac civilis. Buda, 1841. Vol. 10/4. P.76 (doc. no. VIII). For rulers' oaths as confirmation of political pacts, see: Rácz L. Rulers' Oaths in the Kingdom of Hungary and in the Principality of Transylvania // Le Serement. I. Signes et Fonctions / ed. by R. Verdier. Paris, 1992. P.432; for oaths on relics generally, see below.

${ }_{10}$ Engel P. Realm of St Stephen. P. 207.

11 This was an unusual move, as the office of palatine was normally held for life. For this institution, see especially: Szöcs T. A nádori intézmény korai története 1000-1342. Budapest, 2014; Tóth N. C. A Magyar Királyság nádora. A nádori és helytartói intézmény története (1342-1562). Budapest, 2017.

12 Engel P. Realm of St Stephen. P. 207.

13 For this event, see especially: Bunyitay $V$. A váradi püspökség története alapításától a jelenkorig. Nagyvárad, 1883. Vol.1. P.220-221; Klaniczay G. La noblesse et le culte des saints dynastiques sous les rois angevins // La noblesse dans les territoires Angevins à la fin du Moyen Âge. Actes du colloque international organisé par l'Université d'Angers, Angers-Saumur, 3-6 juin 1998. Rome, 2000. P. 525; Năstăsoiu D.-Gh. Between Personal Devotion and Political Propaganda: Iconographic Aspects in the Representation of the sancti reges Hungariae in Church Mural Painting (14 $4^{\text {th }}$ Century - Early-16 $6^{\text {th }}$ Century). Budapest, 2018. P. 123.

14 "...dum in dictum Regnum Bohemie in subsidium excellentissimi principis domini Wencezlai fratris nostri eiusdem Regni Bohemie regis laborassemus, quidam prelati et Barones necnon proceres maior scilicet pars dicti Regni nostri Hungarie in opprobrium nostre celsitudinis in quo freti consilio in vnum conspirantes Waradinum conuenerunt, vbi prestito Juramento super capite sancti Regis Ladislai corporaliter facto nos dyademate Regnisque Hungarie Dalmacie Croacie nostris Regys pretitulatis que fere annis sedecim gubernauimus more Regio in eisdem Imperantes priuare de eisdem Regnis nostris excluere, ac ignotum eis alium Regem scilicet predictam Ladizlaum filium condam Karuli de Duracio inducere, pro eorumque domino eligere et assumpmere conati extiterunt" (Ipolyi A., Nagy E., Véghely D. Codex Diplomaticus Patrius Hungaricus: in 8 vols. Vol.7. Budapest, 1880. P.439-440 (doc. no. 401)). For a list of conspirators, see Hóman B. Angioini, 520. 


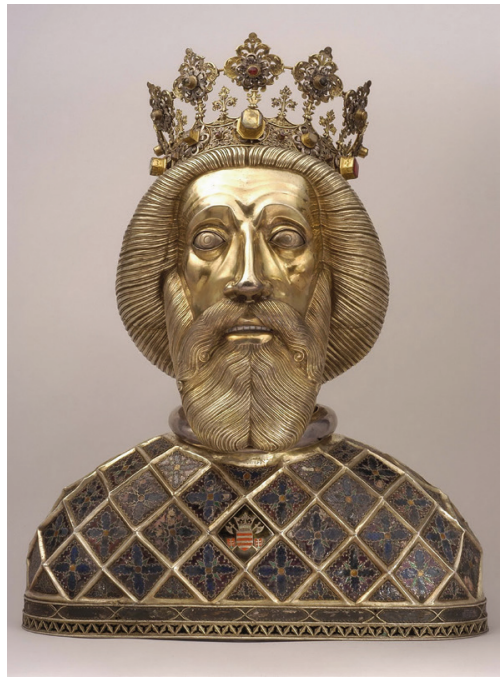

Fig. 2. St. Ladislas' bust reliquary, second half of the $14^{\text {th }}$ century or early- $15^{\text {th }}$ century (head), after 1406 (bust), and 1600 (crown), $64,7 \times 51,4 \mathrm{~cm}$, gilt silver and enamel (Cathedral of the Holy Virgin Mary, Győr) garian saintly ruler and God ${ }^{15}$. Additionally, the legal practice of ordeals by hot iron and by oath centering since the early- $13^{\text {th }}$ century around St. Ladislas' tomb and relics in the Cathedral of Nagyvárad played definitely a major role in the choice of object and place for the Hungarian magnates' symbolic gesture ${ }^{16}$. By swearing an oath on the holy king's reliquary, the conspirators united their minds and forces around the ideal figure of St. Ladislas, who became thus the symbol of a political cause and the embodiment of the kingdom which - according to the rebels' views the ruling king was no longer suited to represent ${ }^{17}$.

St. Ladislas' skull is currently housed in an exquisite bust reliquary (now kept in the Cathedral in Györ, but coming originally from the Cathedral of Nagyvárad), which is a composite work made up of several pieces of different ages (Fig. 2): the head is considered the work of either second half of the $14^{\text {th }}$ century or early-15 $15^{\text {th }}$ century, the enameled bust is dated to a period after 1406, whereas the crown was added much later, in $1600^{18}$. If one accepts the head's later dating, then the overall appearance of the reliquary is the result of a post-1406 refashioning sponsored by King Sigismund himself. This refashioning was the consequence of a fire in the early 1400s, which destroyed the cathedral's sacristy and melted down the reliquary - though it left the holy relics unharmed ${ }^{19}$. However, if one accepts its earlier dating, then it was the very same head containing St. Ladislas' skull that the Hungarian noblemen used for taking their oath on and for conspiring against

15 Similar features are noted also by Ančić M. Od tradicije 'sedam pobuna' do dragovoljnih mletačkih podanika. Razvojna putanja Zadra u prvome desetljeću 15. stoljeća // Povijesni prilozi 2009. Vol.28, iss. 37. P.71.

16 For oath-swearing on relics in medieval Hungary, see: Berend B. Oath-taking in Hungary. A Window on Medieval Social Interaction // Central and Eastern Europe in the Middle Ages. A Cultural History. London, 2009. P.42-49, 227-230; Zupka D. Ritual and Symbolic Communication in Medieval Hungary under the Árpád Dynasty (1000-1301). Leiden, 2016. P. 61-68, with examples and bibliography. For ordeals by hot iron in Oradea Mare, see: Makó Lupescu M. Between the Sacred and Profane: The Trial by Hot Iron Ceremony Based on the Regestrum Varadinense // Mediaevalia Transilvanica. 1999. Vol. 3, iss. 1-2. P. 5-26; Zajtay I. Le Registre de Varad. Un monument judiciaire du début du XIIIe siècle // Revue historique de droit français et étranger. 1954. Iss. 31. P. 527-562.

17 Năstăsoiu D.-Gh. Between Personal Devotion... P. 123.

18 The most recent work on the reliquary is: Kristóf L. A., Lukácsi Z., Patonay L. Szent király, lovágkirály. A Szent László-herma és koponyaereklye vizsgálatai. Győr, 2017. See also: Kerny T. Reliquienbüste des hl. Ladislaus // Sigismundus Rex et Imperator. Kunst und Kultur zur Zeit Sigismunds von Luxemburg 1387-1437. Ausstellungskatalog. Mainz, 2006. P.378-382; László Gy. Szent László győri ereklyetartó mellszobráról // Arrabona. 1966. Iss. 7. P. 157-209; Montgomery S. B., Bauer A. A. Caput sancti regis Ladislai: The Reliquary Bust of Saint Ladislas and Holy Kingship in Late Medieval Hungary // Decorations for the Holy Dead. Visual Embellishments on Tombs and Shrines of Saints. Turnhout, 2002. P.77-90.

19 King Sigismund also supported the cathedral's partial rebuilding in 1406-1407 through royal confirmation of privileges and donations (Fejér G. Codex. Vol. 10/4, 518-528, 613-614 (doc. no. CCXXXIIICCXXXV, CCXCII)). 
King Sigismund. Regardless of the accepted date, on Christmas Eve 1402, St. Ladislas' holy remains were kept in a reliquary, whose human-like shape and size helped the conspirators to perceive the relic-containing object as the holy king's actual head ${ }^{20}$. This is indeed apparent from the wording of the 1406 royal charter, which states that the oath was performed on the bodily head of the Holy King Ladislas. Subsequently, in the conspirators' eyes, it was St. Ladislas himself that actively participated in the respective religious and political rituals, overseeing and sanctioning them simultaneously.

By the early 1403, a revolt broke out, Archbishop Kanizsai and former Palatine Bebek being joined by nearly all the high ecclesiastics and magnates of the country, namely: Archbishop of Kalocsa John Szepesi, Prior of Vrana Emeric Bebek (that is, the former palatine's own son), the Bishops of Eger, Nagyvárad, Transylvania, and Györ, or the Voivodes of Transylvania Nicholas Csáki and Nicholas Marcali ${ }^{21}$. According to John of Thurocz's late- $15^{\text {th }}$ century account, the rebels made their way throughout the kingdom, gathered publicly and haughtily in large crowds, and raised the banner of King Ladislas of Naples compelling the clerical order to greet it respectfully in procession whenever the rebels reached a town ${ }^{22}$. Even though such object no longer exists, it is very likely that King Ladislas' banner featured his tripartite armorials that incorporated the Hungarian redand-white stripes arranged horizontally alongside the Angevin golden lilies on a blue background with red label of three points and the golden, five-fold Cross of Jerusalem on a white background (Fig. 3). In any case, it is known that around 1409 during his later Italian exploits King Ladislas adopted the motto "aut Caesar, aut nihil", and had a banner emphatically and demagogically inscribed as "io sono un povero re amico delli saccomanni / amatore delli popoli e distruttore dei tiranni" ${ }^{23}$. The closest visual analogy is offered by a cassone painting illustrating the conquest of Naples by Ladislas' father, King Charles III (r. 1382-1386), and his confrontation in August 1381 with Duke Otto of Brunswick-Grubenhagen, the fourth and last husband of Queen Joanna I of Naples (Fig. 4). This panel was most likely commissioned around 1402 by the depicted king's wife, Margaret of Durazzo (d. 1412), on the occasion of the marriage between their son Ladislas and Mary of Lusignan ${ }^{24}$. The standard-bearers in Charles' army are shown carrying three distinct

${ }^{20}$ For the perception of such human-like reliquaries as the saint's actual, physical presence and their involvement in sacred and political rituals, see: Montgomery S. B. The Saint and the King. Relics, Reliquaries and Late Medieval Coronation in Aachen and Székesfehérvár // Matter of Faith. An Interdisciplinary Study of Relics and Relic Veneration in the Medieval Period. London, 2014. P.32-39. See also: Hahn C. Strange Beauty. Issues in the Making and Meaning of Reliquaries, 400-circa 1204. University Park, 2001. P. 117-133, 145-160; Hahn C. The Spectacle of the Charismatic Body. Patrons, Artists, and Body-part Reliquaries // Treasures of Heaven. Saints, Relics, and Devotion in Medieval Europe. Baltimore; London, 2011. P. 167-169.

21 Engel P. Realm of St Stephen. P. 207.

22 "Magna igitur in agmina palam convoluti superba cervice gradientes elevato ipsius regis Ladislai vexillo regni per climata ferebantur. Et, cum civitatem ad quamcunque ipso vexillo comite veniebant, sacratus cleri ordo illis processionali cum veneratione obviam ire compellebatur" (de Thurocz J. Chronica Hungarorum. Budapest, 1985. Vol. 1. P.215). King Sigismund's opponents raising King Ladislas' banner and fighting under it during the spring of 1403 are mentioned indeed in: Ipolyi A. Codex. Vol. 7. P. 441 (doc. no. 401); Šišić F. Nekoliko isprava... P. 233 (doc. no. 72).

${ }^{23}$ Cutolo A. Re Ladislao d'Angiò Durazzo. Naples, 1969. P. 416; Gaglione M. 'Converà ti que aptengas la flor.' Profili di sovrani angioini, da Carlo I a Renato (1266-1442). Milan, 2009. P. 605.

24 Mocciola L. La presa di Napoli di Carlo III Durazzo nel pannello del Metropolitan Museum: nuove ipotesi // La battaglia nel Rinascimento meridionale. Moduli narrativi tra parole e immagini. Rome, 2011. P. 57-67, with earlier bibliography. 


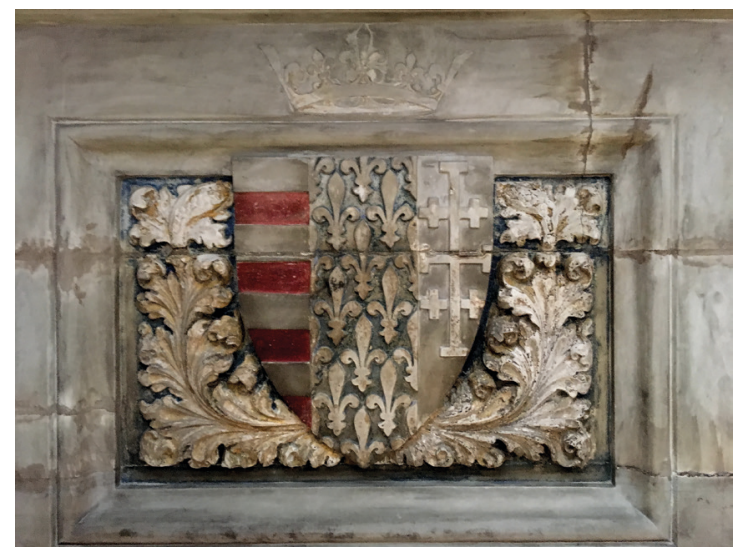

Fig. 3. Coat of arms of King Ladislas of Naples, 1428-1431, painted and gilded marble (Church of San Giovanni a Carbonara, Naples)

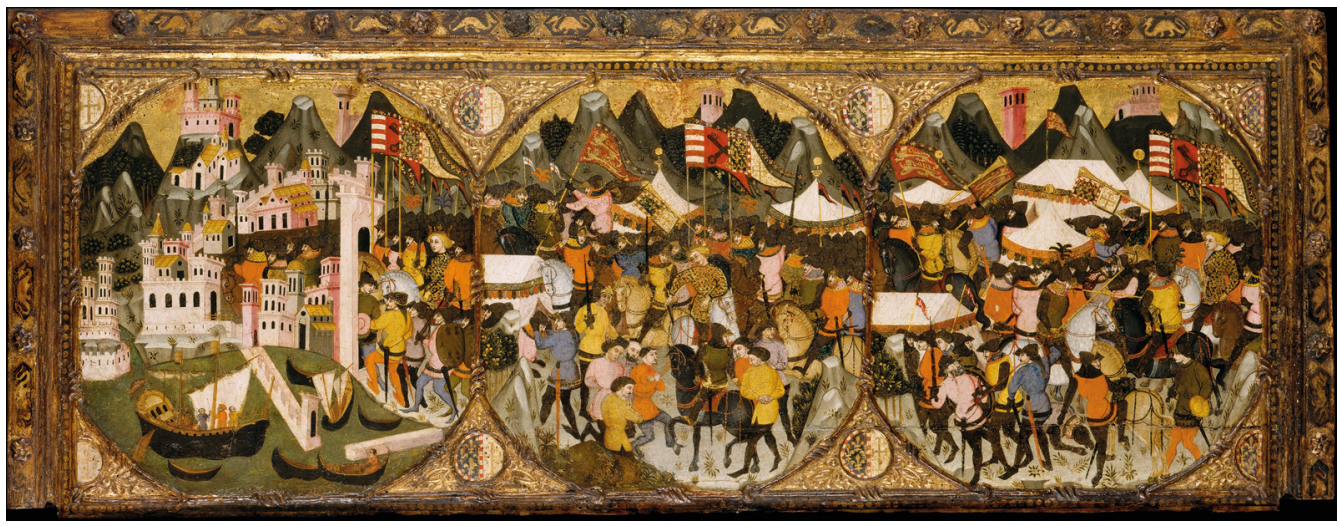

Fig. 4. Conquest of Naples by King Charles III of Naples, ca 1402, tempera on wood, 128,9 × 49,2 cm [Metropolitan Museum of Art, New York, inv. no. 07.120.1]

heraldic banners, namely: the king's personal, tripartite armorials of the Anjou-Durazzo House, having instead the Hungarian stripes surrounding the Angevin lilies; the banner with crossed keys on a red background symbolizing Charles' military and political office of Gonfalonier of the Church; and the Hungarian Angevins' dimidiated coat of arms advocating for the king's own claims to the throne of Hungary ${ }^{25}$. However, despite similar, heraldic devices that King Ladislas' supporters may have displayed during the spring of

${ }^{25}$ King Ladislas' parents were first cousins, their grandfather, Duke John of Durazzo (d. 1336), having been the youngest son of the Angevin King Charles II of Naples (r. 1285-1309) and the Árpádian Mary of Hungary (d. 1323). Starting with 1364/5, Ladislas' father lived for years at the Hungarian court of his distant cousin, King Louis I, and he briefly succeeded in being crowned King of Hungary (31 December 1385 24 February 1386). However, he was assassinated not without the knowledge of Dowager Queen Elizabeth of Bosnia (d. 1387), who became regent in the name of her daughter Mary. For this earlier political crisis, see: Engel P. Realm of St Stephen. P. 197-199. 
1403, the towns and the lesser nobility remained greatly faithful to King Sigismund. The contested king relied also on the support of his own barons (for instance, Stibor of Stiboricz of Ostoja, Nicholas Garai, John Maróti, John Perényi, Paul Özdögei Besenyö, Jacob Lack of Szántó, or Ladislas Gordovai). Their prompt military assistance was instrumental in dispersing the rebels within weeks from the revolt's outbreak ${ }^{26}$.

In his attempt at opposing King Sigismund, Archbishop Kanizsai crowned Ladislas of Naples King of Hungary, Croatia, and Dalmatia, but this proved to be too late a measure. Before 5 August 1403, the archbishop performed the coronation of Ladislas in St. Anastasia Cathedral in Zadar, where the former Palatine Detre Bebek, the Archbishop of Kalocsa, and the Bishops of Györ, Nitra, Zagreb, and Veszprém were also present ${ }^{27}$. Pope Boniface IX (1389-1404), who did not favor King Sigismund's attempts at establishing an ecclesiastical policy independent from the papacy ${ }^{28}$ and who generally supported the Hungarian barons' anti-royal actions, sent his legate, Cardinal Angelo Acciaiuoli, to attend the festive event ${ }^{29}$. In a letter sent by Ladislas of Naples to the Venetian Doge on 5 August 1403 , the newly-crowned king described vividly the overcrowded town filled with people of all categories who met his coronation with great joy, enthusiasm, and approval. He then pointed out to the fact that he received all his royal insignia (crown, scepter, and orb) in accordance with the custom of the Kingdom of Hungary ${ }^{30}$. However, this was untrue, as Ladislas' coronation - despite having been performed by the prelate entitled to do so lacked its two other legitimizing conditions. For being considered valid, the coronation should have taken place in the royal basilica in Székesfehérvár and should have been indeed performed by the Archbishop of Esztergom, but with St. Stephen's alleged crown, the Holy Crown of Hungary ${ }^{31}$ (Fig. 5). Assembled from two pieces with different dating and provenance $^{32}$, this composite object was believed to have been sent by Pope Sylvester II (999-1003) to the first Christian King of Hungary, Stephen I (r. 1000/1-1038). Subse-

${ }^{26}$ Ibid. P.207-208; for the events' development, see also: Ipolyi A. Codex. Vol.7. P.440-441 (doc. no. 401).

27 Monumenta Vaticana historiam regni Hungariae illustrantia. Vol. 1/4: Bullae Bonifacii IX. P. M. Pars altera. 1396-1404. Budapest, 1889. P.613-616.

${ }^{28}$ Fedeles T. Az uralkodó, a Szentszék és a magyar főpapok Luxemburgi Zsigmond korában // Mesterek és tanítványok 2. Tanulmányok a bölcsészet- és társadalomtudományok területéröl. Pécs, 2018. P. 81-145.

29 Šišić F. Nekoliko isprava... P. 204-205 (doc. no. 50).

30 “...solum ex profectionis nostre fama prenuntia, ingens infra biduum eorumdem prelatorum, baronum et magnatum aliarumque gentium caterva promiscue supervenit, cuius iam incapax erat dicta civitas et districtus coronationi assumptionique nostre, hic dictus est die, qui licet avidis populis annus visus sit, mox cum affuit, summo omnium assensu et alacritate quam maxima sacrum capiti diadema, sceptrum dextra, levaque pomum, utrumque fortitudinis, iustitie et domini iudex, ceteraque insignia regalia, iuxta morem regni Hungarie suscepimus incrementa, sicque multa iucunditate et gaudio die iste latissimus actus est." (emphasis mine). - Ibid. P.213 (doc. no. 57).

31 For medieval Hungarian coronations, see: Fügedi E. Coronation in Medieval Hungary // Studies in Medieval and Renaissance History. 1980. Issue 3. P. 159-189; Deér J. Heilige Krone Ungarns; Engel P. Realm of St Stephen. P. 128-130; Zupka D. Ritual and Symbolic Communication... P. 36-45; Bak J. M., Pálffy G. Crown and Coronation in Hungary 1000-1916 A. D. Budapest, 2020. For coronations in medieval Europe, see: Bak J. M. Coronations. Medieval and Early Modern Monarchic Ritual. Berkley, 1990.

32 Bogyai T. Über die Forschungsgeschichte der heiligen Krone // Insignia Regni Hungariae. Budapest, 1983. P. 65-89; Tóth E., Szelényi K. The Holy Crown of Hungary. Kings and Coronations. Budapest, 2000; La Sainte Couronne de Hongrie // Acta Historiae Artium Academiae Scientiarum Hungaricae. 2002. Issue 43. P. 3-111; Bak J. M. Holy Lance, Holy Crown, Holy Dexter: Sanctity of Insignia in Medieval East Central Europe // Studying Medieval Rulers and Their Subjects. Central Europe and Beyond. Burlington, 2010. P. 56-65; Deér J. Heilige Krone Ungarns. 


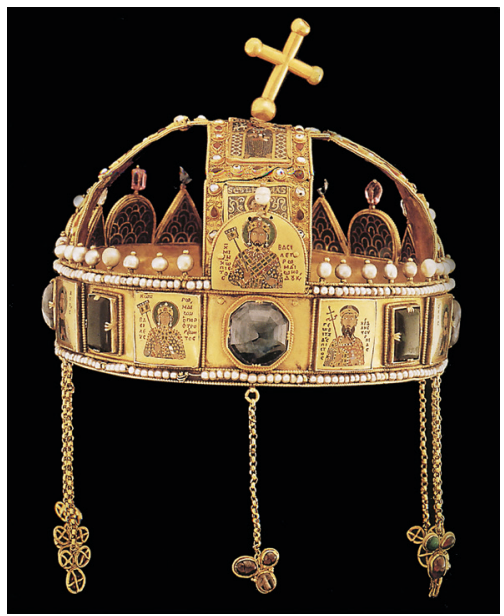

Fig. 5. Holy Crown of Hungary, ca 1075 (corona grae$c a$ ), second half of the $11^{\text {th }}$ century (corona latina), $16^{\text {th }}$ century (cross), gold-silver aloy, enamel, semi-precious stones, and pearls, width 20,9 cm, length 19,8 cm (Hungarian Parliament, Budapest)

quently, the legitimacy of the King of Hungary was derived - among others - from the ceremonial use of this object which was supposed to ideally connect the newly-crowned king with none other than the founder of the Christian Kingdom of Hungary. In this way, St. Stephen sanctioned the investiture of the new king and conferred upon him a set of virtues that the holy king himself possessed and that the new king needed for successful ruling of the country. The lack in validity of King Ladislas' coronation, however, was readily noted by its contemporaries. A royal charter rewarding the loyalty of John Maróti issued by King Sigismund in Székesfehérvár on 5 November 1403, described the ritual as fictitious ${ }^{33}$. In 1404, a document issued by several of the strongest supporters of King Sigismund (Bishop of Zagreb Eberhard Albeni, Ban of Macsó John Maróti, and Bans of Dalmatia, Croatia, and Slavonia Ladislas Gordovai and Paul Özdögei Besenyö) specified that Ladislas of Naples was crowned with a false and improper crown, and contrasted the substitute object to King Sigismund's real, holy crown ${ }^{34}$. If one expects for the contested king and his loyal supporters to hold such views, then the opinion of Ladislas of Naples' own secretary, Matthew of San Miniato, proves that the Zadar coronation was indeed a questionable act. Writing to the town council of Florence on 30 July 1403, the royal secretary informed about King Ladislas' intention to be crowned on the second day of August, despite the lack of adequate coronation props, especially the realm's crown ${ }^{35}$.

33 “...prefato Ladislao filio condam Karuli, ut eorum vota valerent adimplere, ad civitatem nostram Jadryensem conductum prebuerunt, eundem quodam certo fictitio coronantes, ac predicta duo regna nostra, videlicet Dalmatiam et Croatiam..." (emphasis mine). - Šišić F. Nekoliko isprava... P. 233 (doc. no. 72 ).

34 "Quod quia plurimi forent Nobiles, qui hys disturbiorum temporibus $<\ldots>$ potentiis aggregatis, rebusque, consilys et toto posse, contra Serenissimum principem Dominum Sigismundum, regem Hungar. Dalmat. etc. Dominum nostrum naturalem $\langle\ldots\rangle$ acriter insurgendo, in despectum et dedecus sue regie Maiestatis Ladislaum, filium Caroli, regem Sicilie, in predictum regnum Dalmacie in ciuitate videlicet Jadra, producendo, eundem cum falsa et inepta corona coronando, ipsum Dominum nostrum Sigismundum regem $<\ldots>$ sua sacra corona totis ipsorum ingeniis et potentys priuare intendentes..." (emphasis mine). - Fejér G. Codex. Vol. 10/8. P. 469 (doc. no. CCXXXVII).

35 "Vult coronari in proximis diebus et puto fiet actum coronationis die secunda mensis augusti; erit quidem rex extra ordinem suum. Et sonsi coronati in Camaldoli in Belletri re ai miei giorni con più solemnitata che non sia questa. Non cè la corona del reame, perochè è à Visegrado; non ci è il libro consueto; non ci sono altre cose usitate che sono a Alba Reale. Negotium ibit taliter qualiter. Deus det felicem exitum" (emphasis mine). - Šišić F. Nekoliko isprava... P. 211-212 (doc. no. 56). For this and two other letters concerning 
Roughly at the same time with and in opposition to Ladislas' coronation with a substitute crown, King Sigismund himself performed another symbolic coronation. Shortly after his return from Bohemia, during late July 1403, the royal army surrounded and took over Kanizsai's archiepiscopal residence in Esztergom and - after he had the Holy Crown brought from the nearby Visegrád - Sigismund set it publicly upon his head ${ }^{36}$. Since his rule had been contested, King Sigismund needed to symbolically reenact his inauguration to the throne of Hungary showing that it was he who was the real lord of the realm. In terms of symbolic communication in the medieval world, such solemn wearing of the crown during public performances was understood as a reinstatement of the royal rank and legitimacy of power, and was sometimes undertaken to restore social unity and cohesiveness around the sovereign's figure ${ }^{37}$.

Soon after his coronation, King Ladislas returned to Naples, appointing Grand Duke of Bosnia Hrvoje Vukčić Hrvatinić Duke of Split and Ban of Croatia and Dalmatia and entrusting him with the Adriatic affairs of his newly-extended realm ${ }^{38}$. In the following months, the contested king managed to restore the order securing his complete victory and pacifying the whole kingdom by the spring of 1404. Subsequently, King Sigismund pardoned all those who surrendered before a fixed date, promising to restore their possessions and to cancel the grants he had made in their detriment during the revolt. Detre Bebek and John Kanizsai, who did not lay down their arms before the term expired, were accorded a special pardon but some of their castles were confiscated, and Esztergom itself was taken into royal hands for some years ${ }^{39}$. Even though King Sigismund's authority was never fully restored in Dalmatia, the control over the province that King Ladislas exercised vicariously was not going to last either. Six years later, in 1409, in need of money for sponsoring his war against the Republic of Florence, the Neapolitan ruler sold his rights over the Kingdom of Dalmatia to the Republic of Venice for 100.000 ducats $^{40}$.

As this scrutiny of textual and visual sources has revealed, during the political crisis of 1401-1403, Hungarian noblemen utilized a wide range of propaganda tools meant to prove the legitimacy of their anti-royal actions. They resorted constantly to important spiritual and political symbols associated with the realm, such as the Holy Crown of Hungary, the heraldry of the country, or the cult and relics of St. Ladislas. When forming the Council of the Holy Crown and endowing it with a seal whose heraldry symbolized the realm rather than the ruler, the commonwealth of Hungarian magnates asserted its sovereignty in the detriment of the changing person of the king, and strived for attaining the general good of the realm. For this purpose, they even engaged in military combat raising the heraldic banner of King Ladislas of Naples and fighting under it against the contested

King Ladislas' arrival and stay in Zadar, all written by the royal secretary, see: Polidori F.-L. Vite di illustri italiani inedite o rare con illustrazioni. Florence, 1843. P.216-220.

36 Engel P. Realm of St Stephen. P. 208. "Demum ad Strigonium accedentes, castrum cum multitudine gencium circumvallavimus, muniendo circa illud custodibus, ne quispiam ab ipso quoquomodo evadat nobis invisis. Deinde castrum nostrum Vissegradiense visitando, coronam nostram sacram vidimus, et congregato ibidem universo populo, comiti nostro Corbavie, fideli nostro, eam committentes. Tandem reversi ad Strigonium, illud cum bonis et condecentibus fortaliciis una cum bonis et fidelibus gentibus tenemus obsessum" (emphasis mine). - Šišić F. Nekoliko isprava... P. 218-219 (doc. no. 62).

37 For distinction between different types of coronation and their application to medieval Hungary, see: Zupka D. Ritual and Symbolic Communication... P. 36-45, with examples and bibliography.

${ }^{38}$ Engel P. Realm of St Stephen. P. 208.

39 Ibid.

40 Ančić M. Od tradicije... P. 73-76. 
King Sigismund of Luxemburg. The propagandistic usage of these heraldic, political, and spiritual symbols was reinforced by their insertion into elaborated rituals and symbolic actions, such as coronations and oath-swearing on holy relics. Before 5 August 1403, in St. Anastasia Cathedral in Zadar, the Archbishop of Esztergom crowned Ladislas of Naples King of Hungary, Dalmatia, and Croatia, but this gesture was counterbalanced by King Sigismund's own symbolic coronation performed instead with the sole legitimate object, St. Stephen's Holy Crown of Hungary. During a brief moment of reconciliation, the contested King Sigismund swore a solemn oath on the Wood of the Holy Cross promising to comply with the magnates' demands, whereas the Hungarian noblemen themselves swore their allegiance to Ladislas of Naples on the relics of one of Hungary's holy kings. Involved in such a religious and political ritual, the human-shaped reliquary of St. Ladislas signified that the holy king himself took part in these symbolic actions, overseeing and sanctioning them. In the context of the early- $15^{\text {th }}$ century political crisis, the appropriation of St. Ladislas' ideal figure became the driving force behind the Hungarian noblemen's political cause. The participation of St. Ladislas in such a ritual or King Sigismund's oath on the Holy Cross were meant to activate the link between secular and religious spheres, with the performers hoping to attract the divine approval in this way. However, a positive outcome for symbolic and ritual actions was not always granted by divinity, as illustrated by the anti-royal coalition's failure to achieve its goal. By describing the troubled political context of the early- $15^{\text {th }}$ century in the Kingdom of Hungary and by emphasizing the complex symbolic actions and heraldic devices employed for the purpose of anti-royal propaganda, this essay serves as introduction for another study. This second essay deals instead with the artistic and pious patronage of the main actors of the 1401-1403 political crisis. On the one hand, their patronage is characterized by a constant reliance on the cults and images of St. Ladislas and the other two sancti reges Hungariae as a means of expressing political and propagandistic messages. On the other hand, it is distinguished by the incorporation - for political and self-representational purposes - of the realm's heraldry into the personal coats of arms of these Hungarian noblemen.

\section{References}

Ančić M. Od tradicije 'sedam pobuna' do dragovoljnih mletačkih podanika. Razvojna putanja Zadra u prvome desetljeću 15. stoljeća. Povijesni prilozi, 2009, vol.28, iss. 37, pp. 43-96.

Bak J. M. Coronations. Medieval and Early Modern Monarchic Ritual. Berkley, University of California Press, 1990, $257 \mathrm{p}$.

Bak J. M. Holy Lance, Holy Crown, Holy Dexter: Sanctity of Insignia in Medieval East Central Europe. Studying Medieval Rulers and Their Subjects. Central Europe and Beyond. Eds B. Nagy, G. Klaniczay. Burlington, Ashgate, 2010, pp. 56-65.

Bak J. M. Königtum und Stände in Ungarn im 14.-16. Jahrhundert. Wiesbaden, Steiner, 1973, 195 p.

Bak J.M., Pálffy G. Crown and Coronation in Hungary 1000-1916 A. D. Budapest, MTA BTK TTI-MNM, 2020.

Bard I. N. Aristocratic Revolts and the Late Medieval Hungarian State, A. D. 1382-1408. PhD diss. Washington, University of Washington, 1978, $418 \mathrm{p}$.

Berend N. Oath-taking in Hungary. A Window on Medieval Social Interaction. Central and Eastern Europe in the Middle Ages. A Cultural History. London, I. B. Tauris, 2009, pp. 42-49, 227-230.

Bertényi I. Címerváltozatok a középkori Magyarországon. Levéltári közlemények, 1998, vol.59, iss. 1, pp. 3-80.

Bunyitay V. A váradi püspökség története alapitásától a jelenkorig. Vol. 1: A váradi püspökok a püspökség alapításától 1566. évig. Nagyvárad, [s. n.], 1883, 473 p. 
Burkhardt J. Ein Königreich im Wandel: Ungarn um 1400. Biuletyn Polskiej Misji Historycznej. Bulletin der Polnischen Historischen Mission, 2016, iss. 11, pp.407-437.

Cutolo A. Re Ladislao d’Angiò Durazzo. Naples, Arturo Berisio Editore, 1969, 541 p.

de Thurocz J. Chronica Hungarorum. Vol. 1: Textus. Budapest, Akadémiai Kiadó, 1985, 332 p.

Deér J. Die Heilige Krone Ungarns. Vienna, Böhlau, 1966, 301 p.

Engel P. The Realm of St Stephen. A History of Medieval Hungary, 895-1526. London, I. B. Tauris, 2001, 452 p.

Fedeles T. Az uralkodó, a Szentszék és a magyar föpapok Luxemburgi Zsigmond korában. Mesterek és tanítványok 2. Tanulmányok a bölcsészet- és társadalomtudományok területéröl. Pécs, A Pécsi Tudományegyetem Bölcsészettudományi Kar Tudományos Diákköri Tanácsának kiadványa, 2018, pp. 81-145.

Fejér G. Codex diplomaticvs Hungariae ecclesiasticvs ac civilis. Buda, Typis Typogr. Regiae Vniversitatis Vngaricae, 1841, vol. 10/4, $896 \mathrm{p}$.

Fügedi E. Coronation in Medieval Hungary. Studies in Medieval and Renaissance History, 1980, New Series, iss. 3, pp. 159-189.

Gaglione M. 'Converà ti que aptengas la flor.' Profili di sovrani angioini, da Carlo I a Renato (1266-1442). Milan, Lampi di stampa, 2009, 792 p.

Hahn C. Strange Beauty. Issues in the Making and Meaning of Reliquaries, 400-circa 1204. University Park, The Pennsylvania State University Press, 2001, 302 p.

Hahn C. The Spectacle of the Charismatic Body. Patrons, Artists, and Body-part Reliquaries. Treasures of Heaven. Saints, Relics, and Devotion in Medieval Europe. London, The British Museum Press, 2011, pp. 163-172.

Hóman B. Gli Angioini di Napoli in Ungheria 1290-1403. Rome, Reale Accademia d'Italia, 1938, 580 p.

Ipolyi A., Nagy E., Véghely D. Codex Diplomaticus Patrius Hungaricus. Hazai Okmánytár. Vol. 7. Budapest, Kocsi Sándor, 1880, 496 p.

Kerny T. Reliquienbüste des hl. Ladislaus. Sigismundus rex et imperator. Kunst und Kultur zur Zeit Sigismunds von Luxemburg, 1387-1437. Ausstellungskatalog. Mainz, Philipp von Zabern, 2006, pp.378-382.

Kerny T. Szent László tiszteletének kutatástörténete (1977-2007). Arrabona, 2008, vol. 46, iss. 1, pp. 15-35.

Klaniczay G. A Szent László kultusz kialakulása. Nagyvárad és Bihar a korai középkorban. Tanulmányok Biharország történetéröl. Nagyvárad, Varadinum, 2014, pp.7-39.

Klaniczay G. La noblesse et le culte des saints dynastiques sous les rois angevins. La noblesse dans les territoires Angevins à la fin du Moyen Âge. Actes du colloque international organisé par l'Université d'Angers, Angers-Saumur, 3-6 juin 1998. Rome, École française de Rome, 2000, pp.511-526.

Kristóf L.A., Lukácsi Z., Patonay L. Szent király, lovágkirály. A Szent László-herma és koponyaereklye vizsgálatai. Győr, Győri Hittudományi Főiskola, 2017, 247 p.

Kumorovitz B. L. A magyar címer kettőskeresztje. Turul, 1941, vol. 55, iss. 3-4, pp. 45-62.

La Sainte Couronne de Hongrie. Acta Historiae Artium Academiae Scientiarum Hungaricae, 2002, issue 43, pp.3-111.

László Gy. Szent László győri ereklyetartó mellszobráról. Arrabona, 1966, iss. 7, pp. 157-209.

Makó Lupescu M. Between the Sacred and Profane: The Trial by Hot Iron Ceremony Based on the Regestrum Varadinense. Mediaevalia Transilvanica, 1999, vol.3, iss. 1-2, pp. 5-26.

Marosi E. Magyarországi müvészet 1300-1470 körül. Vol.2. Budapest, Akadémiai Kiadó, 1987, 937 p.

Mocciola L. La presa di Napoli di Carlo III Durazzo nel pannello del Metropolitan Museum: nuove ipotesi. La battaglia nel Rinascimento meridionale. Moduli narrativi tra parole e immagini. Rome, Viella, 2011, pp. 57-67.

Montgomery S. B. The Saint and the King. Relics, Reliquaries and Late Medieval Coronation in Aachen and Székesfehérvár. Matter of Faith. An Interdisciplinary Study of Relics and Relic Veneration in the Medieval Period. London, The British Museum Press, 2014, pp.32-39.

Montgomery S. B., Bauer A. A. Caput sancti regis Ladislai: The Reliquary Bust of Saint Ladislas and Holy Kingship in Late Medieval Hungary. Decorations for the Holy Dead. Visual Embellishments on Tombs and Shrines of Saints. Turnhout, Brepols, 2002, pp.77-90.

Năstăsoiu D.-Gh. Between Personal Devotion and Political Propaganda: Iconographic Aspects in the Representation of the sancti reges Hungariae in Church Mural Painting (14 $4^{\text {th }}$ Century - Early-16 ${ }^{\text {th }}$ Century). PhD diss. Budapest, Central European University, 2018, 542 p. 
Rácz L. Rulers' Oaths in the Kingdom of Hungary and in the Principality of Transylvania. Le Serement. I. Signes et Fonctions. Paris, Éditions du C. N. R. S., 1992, pp.425-437.

Solymosi L. Szent László király sírja, kultusza és szentté avatása. Szent király, lovágkirály. A Szent László-herma és koponyaereklye vizsgálatai. Győr, Győri Hittudományi Főiskola, 2017, pp. 16-39.

Szentpétery I. Az országos tanács 1401-ben. Századok, 1904, 38, pp. 759-767.

Szőcs T. A nádori intézmény korai története 1000-1342. Budapest, MTA Támogatott Kutatócsoportok Irodája, 2014, $331 \mathrm{p}$.

Šišić F. Nekoliko isprava iz početka XV st. Starine, 1938, vol.39, pp. 129-320.

Tóth E., Szelényi K. The Holy Crown of Hungary. Kings and Coronations. Budapest, Kossuth Publishing, 2000, 79 p.

Tóth N.C. A Magyar Királyság nádora. A nádori és helytartói intézmény története (1342-1562). Budapest, MTA-HIM-Szegedi Tudományegyetem-Magyar Országos Levéltár, 2017, 304 p.

von Bogyai T. Über die Forschungsgeschichte der heiligen Krone. Insignia Regni Hungariae. Studien zur Machtsymbolik des mittelalterlichen Ungarn. Budapest, Ungarischen Nationalmuseum, 1983, vol.1, pp. 65-89.

Zajtay I. Le Registre de Varad. Un monument judiciaire du début du XIIIe siècle. Revue historique de droit français et étranger, 1954, iss. 31, pp. 527-562.

Zupka D. Ritual and Symbolic Communication in Medieval Hungary under the Árpád Dynasty (1000-1301). Leiden, Brill, 2016, 224 p.

Статья поступила в редакцию 19 августа 2020 г.

Рекомендована в печать 10 декабря 2020 г.

Received: August 19, 2020

Accepted: December 10, 2020 